\title{
Entertainment outreach projects without losing scientific content: A Neolithic puppet show by senior citizens and Roma women in Barcelona (Spain)
}

Millán MOZOTA
Institución Milá y Fontanals de Investigación en Humanidades, CSIC
millanm@imf.csic.es
Santiago HIGUERA
Casal de Barri Folch i Torres
Vanessa GUZMĀN
Departament d'Educació de la Generalitat de Catalunya
Gerard REMOLINS
RegiraRocs S.L.
Juan F. GIBAJA

\section{ABSTRACT}

In this paper, we present the genesis, development and results of a set of inclusive outreach activities developed through a puppet theatre play about the Neolithic. We present our methodology and techniques for outreach activities, showing the advantages of collaborative work and bottom-up approaches. The text also explains how the initiative was born and how the contacts for its realization were consolidated. All the activities were carried out with the utmost care for the scientific content, since it is essential that the public comes to understand the archaeological information presented and is able to differentiate it from the entertaining and dramatic elements.

\section{KEYWORDS}

Community Archaeology; Bottom-up; Scientific Outreach; Inclusion; Neolithic

\section{AP: Online Journal in Public Archaeology - Volume 11 - ISSN: 2171-6315}

Mozota, M. et al. 2021. Entertainment outreach projects without losing scientific content: A Neolithic puppet show by senior citizens and Roma women in Barcelona (Spain). AP: Online Journal in Public Archaeology 11, a1-a16.

DOI: $10.23914 / a p . v 11 i 0.273$

Received: 11/08/2020 :: Accepted: 19/11/2020 


\section{a2 :: AP Journal v.11 :: ARTICLE}

This work is dedicated to the memory of Maria Casas and the women of El Raval

\section{Introduction}

In recent years, many archaeology-related studies have shown an interest in the benefits of disseminating and socializing our discipline: i.e., there is a trove of publications using such terms as 'public archaeology', 'community archaeology' and 'democratization of archaeological communication' (Matsuda and Okamura 2011; Almansa 2013; Almansa et al. 2015; Richardson and Almansa 2015; Moshenska 2017).

These works are relevant as they give rise to an awareness of the importance of scientific dissemination and the democratization of archaeology, which is a positive advancement by all means. Further, they have highlighted many deficiencies and needs of the scientific community related to our interaction with society at a multitude of levels.

However, one might think that researchers actually implementing outreach programmes design them for all kinds of public. But in our experience, this is not always true. Most activities focus on very specific mainstream groups: children, teenagers, middle-class and upper-middle-class families, or, in some cases, tourists. This leaves aside numerous collectives that do not enjoy science in the way that many others are regularly able to. For example, people with disabilities, newly arrived immigrants, the prison population, senior citizens and communities in permanent danger of social exclusion, such as the Roma community with which we are currently working.

How many people are not usually able to participate in outreach activities due to the fact that they belong to such groups? This is a difficult figure to quantify but, as a starting point, we can consider the demographic weight of the aforementioned social groups: according to Eurostat data', in 2015, one in every seven people in the European Union (i.e. about 64 million people) suffered from some disability. Information for 2019 shows that 21.8 million non-EU-27 citizens live in the EU-27 states. In the same year, citizens over 65 years of age represented $19.2 \%$ of the population. Finally, the 'Fundación Secretariado Gitano ${ }^{2 \prime}$ estimates that throughout Europe live about 11 million Roma individuals.

We note that many educators, academic staff, politicians and museum curators, among others, rarely think of those groups when they design their outreach programmes. The exclusion of these collectives is so widespread that society, in general, does not think about them visiting a museum or an exhibition.

1 https://ec.europa.eu/eurostat/statistics

2 https://www.gitanos.org/la_comunidad_gitana/marco_europeo.html.es 
What can we do to change this situation? There are possibly many venues and options, but in this paper we want to contribute by elaborating one example in a highly detailed manner: a case study from our experience within a project of bottom-up archaeological outreach. This case shows the activities developed for and by a group of Roma women and a group of senior citizens from the El Raval neighbourhood of Barcelona. Our role as scientific educators and researchers was to provide context, scientific rigour, global support and the insertion of otherwise excluded collectives and social agents in a net of collaborative work aimed towards community-based outreach.

This case study has been partially covered in other papers from our team (Gibaja etal. 2018; Guzmán et al. 2019; Gibaja et al. 2022) but to date it has never been presented with the depth of the present work. It is important to note that contribution from scientists-educators was ever-present, ensuring the content and scientific rigour of the activities, so that all individuals participating directly or indirectly could differentiate the scientific knowledge from playful, entertaining, humorous, dramatic or narrative elements.

We hope that our experience will be a guide for other researchers and educators so that, ultimately, we can achieve a more inclusive science, in which all the collectives in our society can participate and enjoy.

\section{El Raval neighbourhood and the research and outreach specialists from Institución Milá y Fontanals (IMF-CSIC)}

Barcelona is the capital of Catalonia and the second-most-populous municipality of Spain, with 1.6 million habitants within the city limits. It is a city of wild contrasts, with very rich neighbourhoods and gentrified areas lying side-by-side with other districts with high levels of poverty, unemployment and prevalence of drug addiction. El Raval neighbourhood, within the Ciutat Vella district, is one such area where poverty, unemployment and drug addiction are serious problems.

The CSIC institute "Institución Milá y Fontanals de Investigación en Humanidades" (IMF-CSIC) has been located in El Raval since 1968. Its researchers and outreach specialists have always been acutely aware of the social problems of the surroundings. Therefore, when a senior researcher of the institute, Juan Gibaja, initiated a science education program centred on the El Raval neighbourhood, many other researchers and outreach specialists followed his steps. These dynamics generated a working group that attracted members of other social institutions and associations from the neighbourhood.

Due to the idiosyncrasies of the social groups and communities from El Raval and our interest in social inclusion and accessibility, we focused our efforts on carrying out inclusive outreach activities from the very beginning. We 


\section{a4 :: AP Journal v.11 :: ARTICLE}

were inspired by the work of other colleagues who have worked with different collectives. These experiences not only come from archaeology, but also other scientific disciplines such as astronomy, geology, biology, etc. In any case, they act as a benchmark for how such activities are undertaken, the tools used, and the ethical and methodological principles applied (Phillips and Gilchrist 2012; Gómez et al. 2014; Kajda et al. 2015; Arias-Ferrer and Egea-Vivancos 2017; Iglesias et al. 2017; Fesharaki et al. 2016; Herrero et al. 2017; Masriera-Esquerra 2020; FeliuTorruella et al. 2020).

Additionally, El Raval has a rich historical, cultural and archaeological heritage. Most of the researchers participating in the outreach activities also work on archaeological, anthropological or historical projects in the neighbourhood. For example, the PhD dissertation of Juan Gibaja (2002) included the study of many artefacts from the Neolithic necropolis of Sant Pau del Camp. This is one of the most important funerary contexts from Catalonia, and therefore we decided to include the site in many outreach activities in El Raval. In this way, El Raval communities and social groups also benefit from our ongoing research programs.

This works the other way around too. In most cases, the researchers and outreach specialists started their collaborations in the neighbourhood with a topdown perspective. We offered science education "packages" and activities to different groups and communities. But soon we realized that these groups and communities were more interested in appropriating the science education and outreach activities for and by themselves. They preferred to build a collaboration with us with a bottom-up perspective. The researchers and outreach specialists of the science education team were delighted with the situation: we learned the lesson and adapted our methods to include this new and refreshing perspective. Nowadays, the bottom-up approach is a core element of our programs. Nevertheless, we understand that sometimes a starting spark, or even some help, is necessary. In some cases, the individuals from these groups have been isolated from science throughout their entire lives, and they are unable to conceive that they have a right to it; that science is also for them.

\section{Methods and techniques}

From our working experience, we have elaborated a series of phases based on our practical know-how. This represents an empathic and gradual approach to different groups. We use this approach as a general guide for collaboration with a collective. In this way, scientific outreach becomes inclusive and empowering.

- Phase 0: Exploration of the concepts that participants already know, and their previous ideas, as well as their interests, activities and idiosyncrasies. 
:: Mozota et al. - Entertainment outreach projects without losing... :: a5

- Phase 1. Trust and participation. In the presentation of the activities, we establish a positive environment and trust among the participants, educators and researchers. This facilitates everyone's contribution and participation.

- Phase 2. Promotion of values through activities. Integration and cooperation among participants is encouraged, as well as their self-esteem, their collective value, and their willingness to acquire new knowledge.

- Phase 3. Transfer of knowledge. We critically evaluate the transmission of scientific knowledge, while encouraging participants to transmit the concepts, experiences and knowledge acquired to their immediate social circles.

All these phases require simple and clear language. This is essential in any outreach activity, but it is even more important for people who have not completed their education or have any functional or sensory diversity.

Difficulty in understanding some concepts can be minimized through a broad range of educational tools and active participation. In our experience, practical and experimental activities achieve the best results.

It is also important to maintain the rigour of scientific information. Facts, theories, data and interpretations must be differentiated from purely playful or artistic elements in the dissemination activities carried out with these groups. Furthermore, language must take into account aspects such as gender relations and roles, religious beliefs, cultural and social differences, etc.

The places where we carry out the dissemination activities are also important. It is vital to bring outreach activities to the locations where these groups go about their livelihoods. Activities can be offered in public spaces such as streets and squares, social centres, cultural or neighbourhood associations, commercial premises, etc.

On the other hand, the evaluation has become one of our key elements in dissemination. It provides the tools and knowledge to evolve and improve. For the activities we describe here, the evaluation included:

- Participant observation of an educational psychologist during some of the activities.

- Detailed documentation: Recording of notes, photos and videos of the activities.

- Direct consultations with the participants, social workers, educators and families that accompany the different groups and audiences (Fig. 1). This started as a satisfaction questionnaire (Fig. 1b), but we are currently working on more detailed surveys about knowledge transfer and other aspects. 


\section{a6 :: AP Journal v.11 :: ARTICLE}

- Detailed questionnaires and interviews of the researchers-educators participating in the activities by the educational psychologist (Fig. 1a).
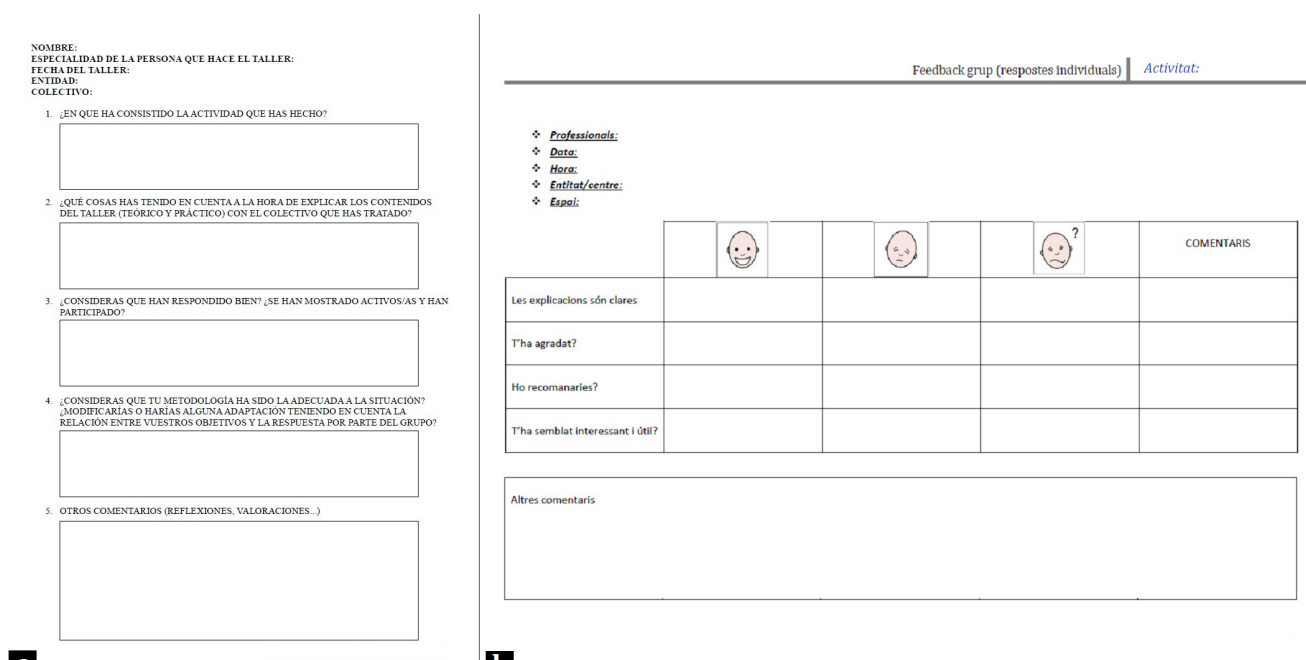

a

b

Fig. 1: (a) Questionnaire for the researcher-disseminator, designed by the educational psychologist V. Guzman. (b) Questionnaire for the participants of the activities, also designed by V.Guzmán.

After collecting all this information, the educational psychologist examines the data. The analysis produces an assessment that incorporates all positive and negative aspects.

\section{Bottom-up approach}

From our point of view, the bottom-up approach is an extremely effective one, even if it sometimes needs an initial spark (Clark, Smith and Seals 2019; Pierce 2018). In such a context, the communities themselves endorse scientific dissemination and become agents of outreach and protection of heritage. While at the beginning they receive such knowledge, later they research and develop it for themselves. In this sense, we have been working for almost a decade on proposals that promote this kind of outreach approach with groups of senior citizens, people with neurological diseases, young people at risk of social exclusion (especially recently arrived migrants) or groups traditionally marginalized, as in the case of the Roma people.

All these projects have been of great interest for us, but we can highlight two groups from El Raval neighbourhood in Barcelona (Spain) with whom we 
collaborate very actively, and whose work in the field of bottom-up outreach is quite impressive. We refer to the group of senior citizens from the Josep Trueta social centre and to the Roma community from El Raval. The Josep Trueta social centre, often in collaboration with the Casal de Barri Folch y Torres (another social centre), has a very active community of senior citizens with a strong interest in intellectual and artistic concerns (Gibaja et al. 2018), as do the Carabutsi and InterAcció associations of the Roma people that work in the Raval neighbourhood.

These associations aim to recover the historical memory of the Roma community in Barcelona, as well as to encourage young people to get involved in cultural activities and continue with their basic and secondary studies. The dropout rate of Roma youths in Spain (Parra Toro et al. 2017; Gabarre et al. 2020), and in certain neighbourhoods of Barcelona in particular, is extremely high, and the support work of these associations serves to mitigate this effect.

Both groups worked in an encouraging and proactive way on the development of a Neolithic puppet show, whose plays are still being enacted today, becoming a new tradition and a milestone for social actions carried out in the neighbourhood.

For the following sections, we divide the explanation into two parts: in the first, we detail the experience of working with the collective of senior citizens and the origin of the puppet show. We explain the genesis, objectives, tools and mechanisms created to develop the activities, their trajectory and the assessment of the results. In the second part, we expose the reformulation of the actions with the group of Roma people: what they and we (researchers-disseminators) changed, how the activity evolved, and its present-day situation.

\section{Starting context and creation of the play with senior citizens}

Since 2013, we have collaborated in outreach activities in the El Raval neighbourhood of Barcelona (within the urban area designated as the Ciutat Vella district). In our activities, we have attempted to integrate with the local social fabric and the different social agents for a more inclusive scientific outreach. The initial spark that led to the creation of the puppet theatre arose in the celebration of a festival in the Raval neighbourhood: The Festa Major del Raval (held in midJuly). On these days, a parade of "capgrossos" takes place: these are traditional and often parodic figures of social life. The neighbours craft them with traditional materials such as textile, wood and cardboard, and then paint the figures by hand.

In 2014, within the framework of collaboration with social centres such as Casal Folch i Torres and Casal Josep Trueta, we proposed creating a "capgrossa" of a Neolithic woman. We suggested that the crafters could adapt her appearance and clothing to scientific knowledge about that period, within this festive and carnival atmosphere. Thus, we contacted a group of senior citizens who participated in 


\section{a8 :: AP Journal v.11 :: ARTICLE}

the activities of the aforementioned centres. This group designed and crafted the figure with the input of researchers from our team (Fig. 2).

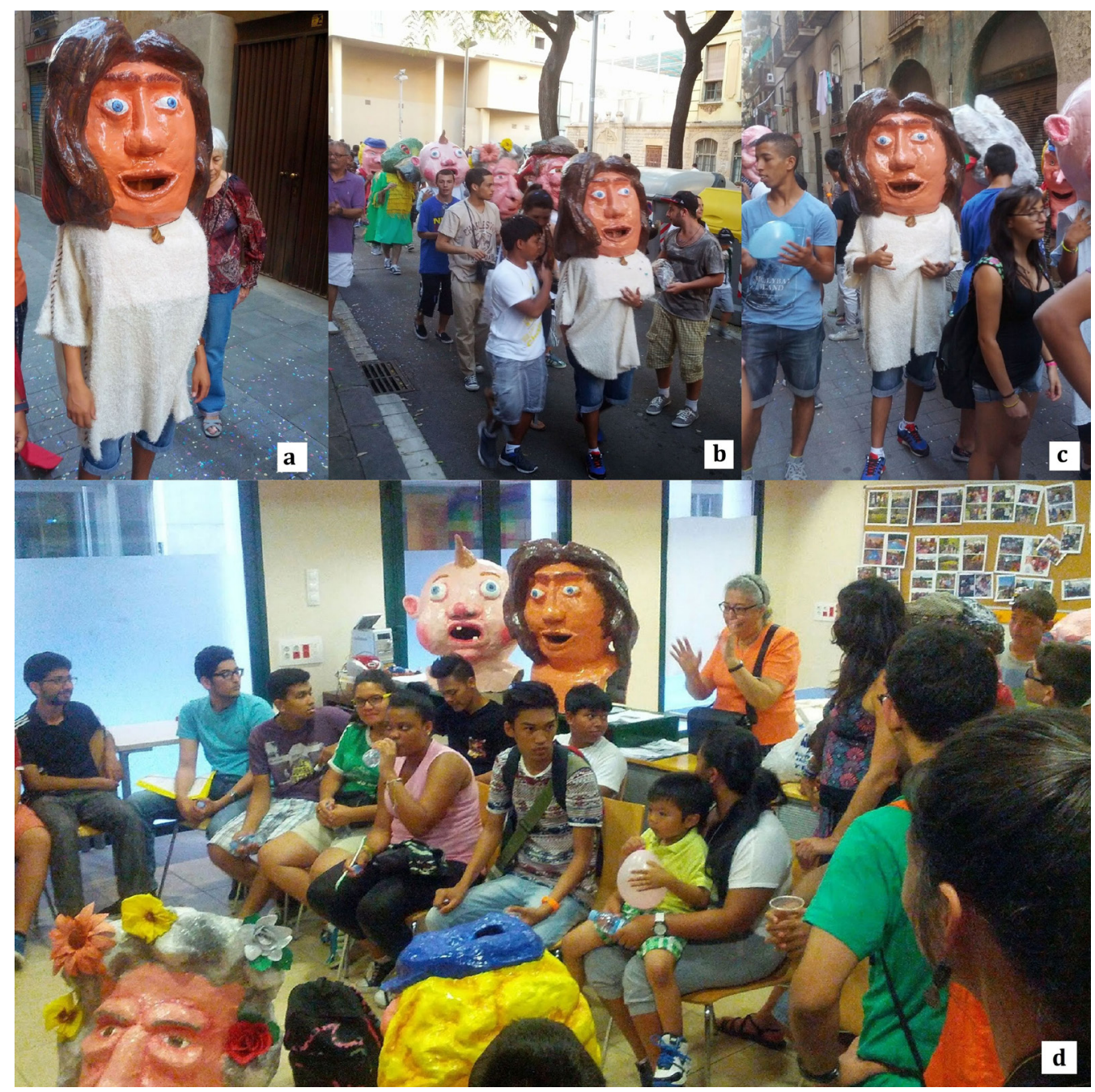

Fig. 2: $(\mathbf{a}, \mathbf{b}, \mathbf{c})$ The Neolithic capgrossa participates in the Festa Major del Raval festival, in a parade that walks and dances through the streets of the neighbourhood. (d) The senior citizen Maria Casas talks to young people and children from El Raval about the Neolithic Capgrossa.

Given the interest shown by this group, we proposed undertaking another joint activity. The group had experience in performing critical and social puppet plays. With that background, they decided to develop a puppet theatre about the Neolithic with the aim of disseminating scientific knowledge. And they did so 
from scratch: they crafted the stage, props and puppets. The senior citizens also wrote a script, advised by the researchers-educators, through which to explain the livelihoods of the first Neolithic societies that lived in the Barcelona area (Fig. 3).

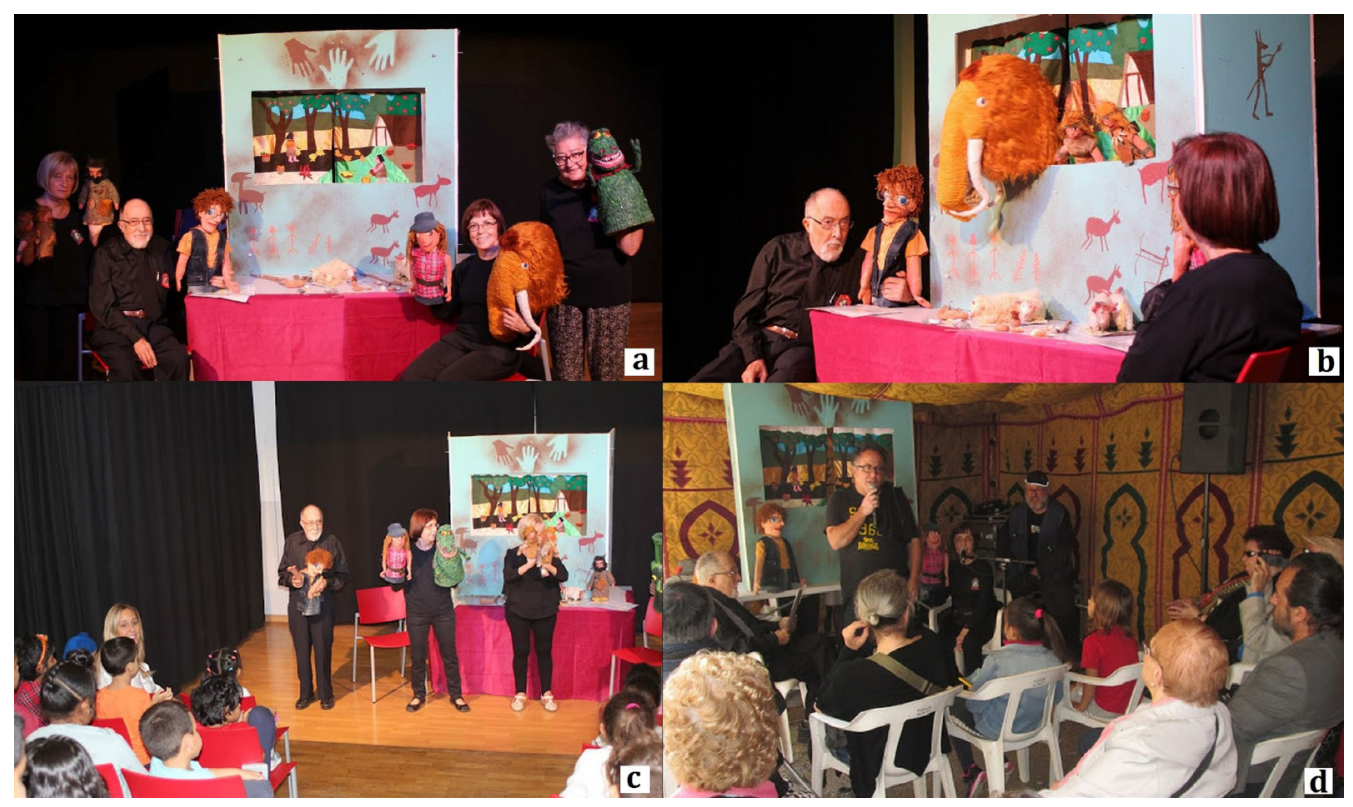

Fig. 3: (a) The Neolithic Puppet Theatre with the senior citizens that were its original creators showing all their materials. (b, c) Performance of the play for children. (d) The play at the 2017 Sant Jordi festival.

The authors of the play wanted to create content adapted for the youngest audiences, so it was a story perfectly adapted to tell to children. Through dialogues, the actors explained a story about archaeologists and Neolithic peoples. The action began with two archaeologists, a man and a woman, talking about the Neolithic, before moving into prehistory, where the protagonists were a girl and a boy from that period, as well as their pet dog.

During the show, certain elements that did not exist in the Neolithic appeared: a dinosaur, a mammoth, and a glass bottle. They designed the play to be very interactive with the audience: children were asked questions, and they collaborated to keep the elements that belonged (or not) to the Neolithic period inside (or outside) the narrative. When each show was over, a professional archaeologist answered the questions that the attendees might have, clearly and simply, referring to elements of the play as examples. 


\section{a10 :: AP Journal v.11 :: ARTICLE}

The first performance of the play was in 2015, and performances continued until 2018. They were held in social centres and schools throughout Barcelona. The audience that came to the play was mostly children, often accompanied by their parents, other relatives and/or social workers, educators and tutors.

While the puppet theatre activities are the focus of this paper, it must be mentioned that this was not the only area of collaboration with senior citizens from the El Raval neighbourhood. On the contrary, we organized, advised or supported other initiatives with said collective. For example, "open-doors" visits to the Institución Milá y Fontanals (CSIC) research centre and a series of pottery workshops organized with the collaboration of Casal Folch i Torres and Casal Josep Trueta (Gibaja et al. 2018, Guzman et al. 2019, Gibaja et al. 2022).

\section{Reformulation and continuation of the activities with Roma people}

The Neolithic theatre could have continued without changes until today, or it could have ended after several sessions. We were open to both possibilities from the beginning, as we always wanted the senior citizens to decide on the fundamental aspects of the initiative. But what happened, in the end, was something quite unexpected: a transferral and reformulation of the show. This reinterpretation of the play was born, once again, from a bottom-up approach, through the interaction of researchers-educators and the different collectives from El Raval.

In 2018, the senior citizens expressed their desire to quit performing the play for various, mostly personal, reasons. At that time, the researcherseducators of our team worked with two associations of Roma people in different initiatives. The associations were Carabutsi and Inter-Acciò, both representing the Roma community from El Raval. The main collaborative project was about the preservation of the historical memories of the Roma people from El Raval, Barcelona, and Catalonia in general. In this context, we learned that a group of young women from the Roma community were also actresses in popular theatre. They performed short plays of a moral nature in the context of their church services, usually shadow-play puppet shows. Therefore, we suggested to both collectives that, instead of abandoning the initiative of the Neolithic theatre, it could be transferred from one group to the other. Both parties met the proposal with enthusiasm, and began immediately to make it happen.

The senior citizens took up the role of expert advisors and provided all the know-how and the practical experience with the script and the materials. The researchers-educators provided once again the scientific supervision, to ensure the validity of the contents. This transitional period happened around the final months of 2018 (Fig. 4a). 


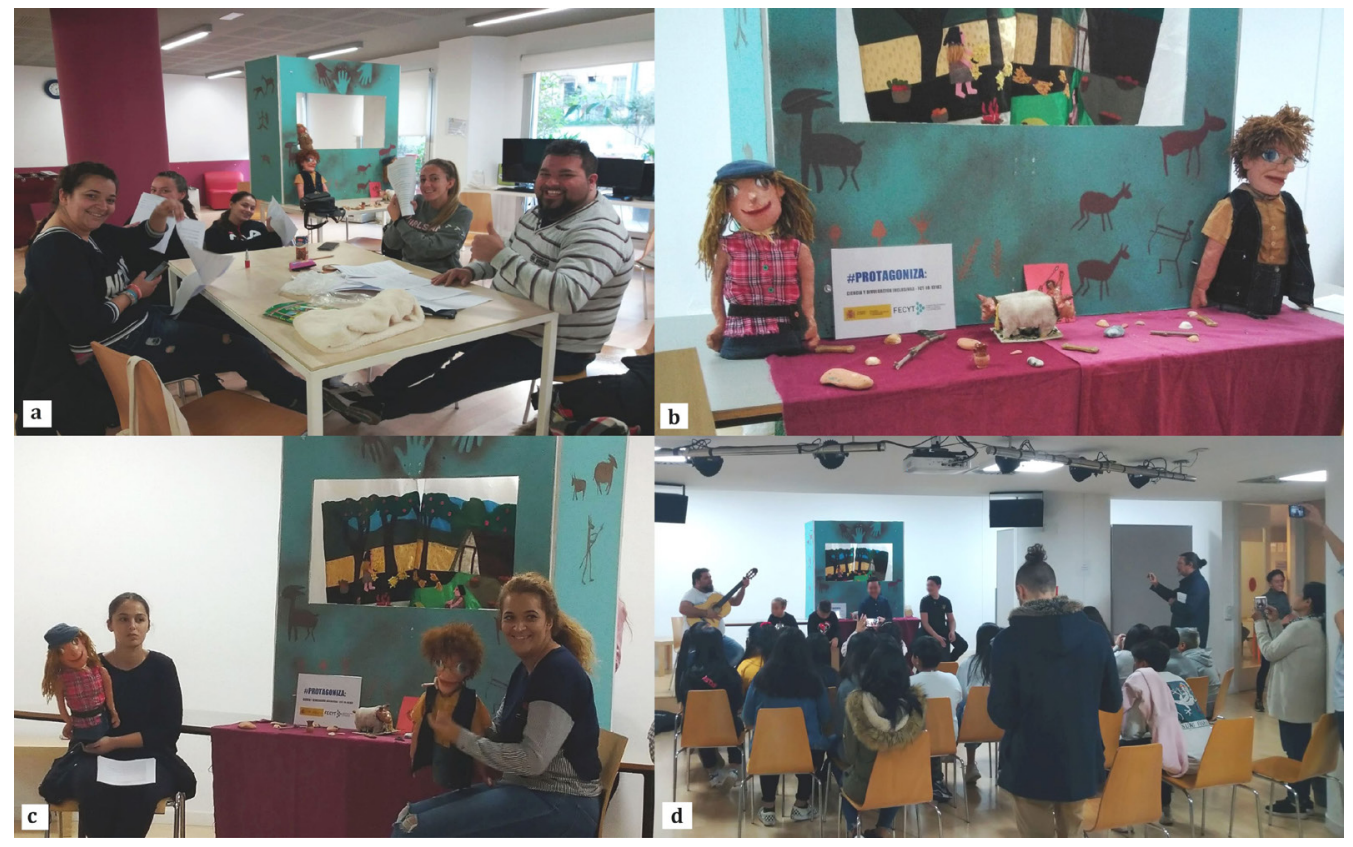

Fig. 4: (a) The Roma group works on the adaptation of the play. (b) The puppet theatre and materials. $(\mathbf{c}, \mathbf{d})$ Performance of the play for children with live music.

An important detail is that the Roma women didn't just inherit the materials continue to perform the play in its original form. They modified the script and made it longer and fresher, always with the complicity of the senior citizens. They also enriched the play with recorded and live music (Fig. 4d). Their musical style is the Catalan rumba, which is a particular style of the Roma communities in the city of Barcelona. The genre originated in the city and is, to some extent, representative of the Roma peninsular community in general. The Rumba was included by adding a musical number performed by Roma musicians, both men and women (usually singers, guitarists and "cajón" percussionists; and sometimes with the participation of dancers, "bailaoras"). Other modern music samples were added to the play, as recurring gags and humorous elements of complicity with the spectators.

In the end, the Roma group has rejuvenated the play and offers a great, fun spectacle which still maintains all of its scientific outreach value. The plays resumed in 2019. The audience that comes to the performances is still mostly children accompanied by their parents, relatives, social workers, teachers, etc. (Fig. 4). In the performances made in El Raval, the attendants are predominantly local newcomers, but when the Roma women have taken the play to other neighbourhoods and districts of Barcelona, they have found different audiences 


\section{a12 :: AP Journal v.11 :: ARTICLE}

of diverse social extraction: outside El Raval, most audiences were middle-class children from public schools, both of whose parents were born in Spain.

\section{Results}

Between 2015 and 2018, the senior citizens carried out performances in the Casal Folch y Torres, Casal Drassanes and El Mil.lenari Day Center, in addition to participating in the 2017 Sant Jordi festival. Their performances appeared in a micro-documentary filmed in the context of our outreach projects that can be viewed on YouTube (Gibaja et al. 2017b).

Roma women carried out a number of performances in 2019, in the Casal Folch y Torres, within the framework of various holidays and festivals of local interest. In November 2019, several European researchers participating in the ENE2019 (Early Neolithic of Europe) international congress attended one of their plays, interested in their content and dissemination techniques. Additionally, both groups have occasionally brought the theatre to the squares and streets of El Raval.

As explained before, the public was mostly young children, with ages generally ranging between 4 and 12 years. Sometimes parents, educators and social workers accompanied them. The attendees' previous levels of knowledge varied, but we found that many of the children knew little about prehistory, other than some distorted ideas derived from television films and cartoons with almost no scientific basis. Therefore, their pre-existing image of prehistoric societies was very different from the current scientific models proposed by researchers. When asked questions prior to the activities, many of them were unable to locate the Neolithic chronologically, and knew very little about the tools and objects that these societies made. They generally thought that dinosaurs and humans had lived at the same time, and did not know the difference between an archaeologist and a palaeontologist.

Based on the questions posed to and by the researchers-educators at the end of the performances, we can conclude that after the activity the children had interiorized these basic concepts. This means that our core goals were successfully met after each iteration of the puppet play. The questionnaires completed by the participants showed an overwhelming satisfaction with the activity. While we agree with this judgement in general terms, we can't believe everything we did was perfect, so we are working upon new, more detailed questionnaires, and also upon complementary protocols and channels for feedback. 
:: Mozota et al. - Entertainment outreach projects without losing... :: a13

\section{Final remarks}

At the time of writing this paper, the Neolithic puppet show has become a milestone of the popular culture life of the El Raval neighbourhood, and each performance draws significant attention from local and regional media. The initiative is continually cited in news from traditional media, websites, blogs and social networks, especially at the local level and in the context of scientific dissemination in Spain.

On the other hand, during these years of working with different groups we have learned a series of important lessons:

- Often, researchers are surrounded by groups that they fail to take into consideration when it comes to scientific outreach. This is mainly due to unconscious biases and preconceptions about outreach and said groups. Therefore we, the researcher-educators, must make a conscious effort to identify these groups and forge contacts with them.

- It is very important to take an interest in the activities of these groups to discover what hobbies and concerns they have. The outreach proposals that work best are, almost always, those inserted within the framework of their concerns, interests and activities.

- Being open to criticism and assessment is a core condition for success, whether it is formal and organized or spontaneous from the participants. Therefore, we must work at all times to create and keep open all possible channels by which we could receive feedback.

On the other hand, we want to emphasize that innovation and renewal of our activities, plans and projects are vital for us. We believe that it is important not to settle with carrying out the same actions with reduced numbers or types of groups. On the contrary, we must continue expanding the groups with which we collaborate. In this sense, in addition to the elderly and the Roma community, we work with people with intellectual disabilities, recently arrived immigrants, children and young people from a variety of social backgrounds, etc. (Gibaja et al. 2016a, Gibaja et al. 2016b, Gibaja et al. 2017a, Gibaja et al. 2018, Guzmán et al. 2019, Gibaja et al. 2022). And very recently we have started working with support groups that help people with mental illnesses and also with the prison population of Catalonia studying in formal education programs. We hope that these new actions will bear fruit and consolidate in the coming years.

Finally, we believe that our general model of collaboration in scientific outreach can be adapted to the dissemination of all types of research, that is, to any discipline. Therefore, we encourage researchers-educators from all fields of science to propose more actions with an inclusive and bottom-up philosophy. 


\section{a14 :: AP Journal v.11 :: ARTICLE}

\section{Acknowledgements}

This project has been made possible thanks to the funding offered by the Spanish Foundation for Science and Technology (FECYT): \#RavalEsCiencia: La Ciencia te acerca al pasado. Raval, una historia de hace más de 6000 años (FCT-13-6944), Integra>Ciencia: Scientific dissemination without barriers (FCT17-11972), \#Protagoniza: inclusive science and dissemination (FCT-18-13183) and \#ProtagonizaDOS: Acciones de ciencia y divulgación inclusivas FCT-19-14670), as well as by the CSIC in its program Cuenta la Ciencia of the CSIC General Foundation: Listen to them! Disseminating for "forgotten" groups (FGCC-20200010). We especially thank all the people, institutions and associations that collaborate with us, and in particular Milá y Fontanals Institute (IMF-CSIC), Casal de Barri Folch i Torres, Casal Josep Trueta, Barcelona City Council, Carabutsí and Inter-Acció associations, and Regirarocs S.L. We want to mention specifically Talita Gabarre, Naomi Amaya, Nayara Batista, Sinay Batista, Miriam Vidal-Ribas, Carmen López, César Martínez, Samuel García, Maria Casas, María Rosa Selvas, Antoni Vergès, Mercè Juan and Lola Alcodori.

\section{Bibliography}

Almansa, J. 2013. Introducción. Hablando de arqueología pública. In Almansa, J. (ed.), Arqueología pública en España. Madrid, JAS Arqueología, 3-12.

Almansa, J., Galmés, A., Abrunhosa, A., Garrochena, E., Cardona, G., Palomero, I., Señoran, J.M., Aparicio, P. and Vizcaíno, A. 2015. Arqueólogo busca público: políticas de integración y el futuro de la arqueología. VII Jornadas de jóvenes en investigación arqueológica, Arkeogazte anexo 1, 339-369.

Arias-Ferrer, L., Egea-Vivancos, A. 2017. Thinking Like an Archaeologist: Raising Awareness of Cultural Heritage Through the Use of Archaeology and Artefacts in Education. Public Archaeology 16 (2), 90-109.

Clark, L. K., Smith, T. B. and Seals, S. R. 2019. Participatory Evaluation of Cultural Heritage Based Programming to Empower Communities. AP: Online Journal in Public Archaeology 9, 65-90.

Feliu-Torruella, M., González-Marcén, P., Masriera-Esquerra, C. 2020. Heritage Education from the ground: Historic Schools, cultural diversity and sense of belonging in Barcelona. In Colomer, L. and Catalani, A. (eds.) Heritage Discourses in Europe today: Responding to Migration, Mobility and Cultural Identities in the 2st Century. Amsterdam, Amsterdam University Press, 53-68.

Fundación Secretariado Gitano. Retrieved on 10 August 2020 from WWW https://www.gitanos.org/la_comunidad_gitana/un_pueblo_sin_fronteras. html.es. 


\section{:: Mozota et al. - Entertainment outreach projects without losing... :: a15}

Gabarre, T., García, S., Martínez, C. 2020. Projecte comunitari de construcción d'un Ecomuseu urbà gitano de Barcelona des d'una perspectiva de gènere (EMUGBA). Revista de Pensament Associativ i Cultura Popular 19, 48-56.

Gibaja, J. F. 2002. La función de los instrumentos líticos como medio de aproximación socio-económica. Comunidades del V-IV milenio cal BC en el noreste de la Península Ibérica. Unpublished PhD thesis, Universitat Autònoma de Barcelona.

Gibaja, J. F., Higuera, S., Borrut, N. and Palomo, A. 2016a. Raval 6000 anys d'Història: un proyecto para aproximar la prehistoria a la ciudadanía. In DíazAndreu, M., Pastor, A. and Ruiz, A. (eds.) Arqueología y comunidad: El valor social del patrimonio arqueológico en el siglo XXI. Madrid, JAS Arqueología, 191-207.

Gibaja, J. F., Higuera, S. and Miró, L. 2016b. "Raval, 6000 años de historia": un proyecto para llevar la arqueología y la prehistoria a la ciudadanía. Cuadiernu: Difusión, Investigación y conservación del patrimonio cultural 4,114-119.

Gibaja, J. F., Vila, A., Higuera, S. and Richaud, I. 2017a. RavalEsCiencia: actuaciones divulgativas en las calles del centro de Barcelona. In Prados, L. and López, C. (eds.) Museos arqueológicos y género. Educando en lgualdad. Servicio de publicaciones UAM, 451-471.

Gibaja, J. F., Torres, R., Serventi, D., Olivella, G. 2017b. La Prehistoria contada con marionetas. YouTube. Retrieved on 10 August 2020 from WWW https://www. youtube.com/watch? $\mathrm{v}=\mathrm{Ifd} 36 \mathrm{dRW}$ _O0.

Gibaja, J. F., Cubas, M., Floro, J., González-Vázquez, A., Guzmán, V., Higuera, S., Mazzucco, N., Mozota, M., Nieto, A., Oms, X., Palma, O., Palomo, A., Remolins, G. and Valenzuela, S. 2018. Las personas de la Tercera Edad. Unos grandes olvidados por la Divulgación Científica. O Ideário Patrimonial 11, 54123.

Gibaja, J. F., Mozota, M., Masriera-Esquerra, C., Nieto-Espinet, A., ValenzuelaLamas, S.; Higuera, S., Guzmán, V., González-Vázquez, A., Oms, X., Cubas, M., Palma, O. and Remolins, G. 2022 [in press]. Inclusive archaeology. 'Forgotten groups' that empower themselves through outreach activities. In Jameson, J. and Baugher S. (eds.) Creating Participatory Dialogue in Archaeological and Cultural Heritage Interpretation. New York, Springer.

Guzmán, V., Gibaja, J. F., Mozota, M., Nieto, A. and Valenzuela-Lamas, S. 2019. ¿Hacemos una correcta divulgación científica en arqueología? O Ideário Patrimonial 12, 54-123.

Matsuda, A.; Okamura, K. 2011. Introduction. In Okamura, K.; Matsuda, A. (eds.) New Perspectives in Global Public Archaeology. New York, Springer, 1-18. 


\section{a16 :: AP Journal v.11 :: ARTICLE}

Masriera-Esquerra, C. 2020 [in press]. Excluded Groups from Cultural Institutions. Whom Do We Communicate with Museums and Cultural Heritage? In Babic, D. and Nezahat-Uralman, H. (eds.) Museums and Communication. ICOMICTOP.

Moshenska, G. 2017. Introduction: public archaeology as practice and scholarship where archaeology meets the world. In Moshenska, G. (ed.) Key Concepts in Public Archaeology. London, UCL Press, 1-13.

Parra Toro, I., Ālvarez-Roldán, A. and Gamella, J. F. 2017. Un conflicto silenciado: Procesos de segregación, retraso curricular y abandono escolar de los adolescentes gitanos. Revista de Paz y Conflictos 10 (1), 35-60.

Pierce, G. 2017. Integrating Research, Outreach, and Education at the Gipson Site. AP: Online Journal in Public Archaeology 7, 39-60.

Richardson, L. J., Almansa-Sánchez, J. 2015. Do you even know what public archaeology is? Trends, theory, practice, ethics. World Archaeology 47 (2), 194-211. 